\title{
Inhibitive Action of Artemisia Plant Extract on the Copper Corrosion in Phosphoric Acid.
}

\author{
F. Mounir', S. El Issami ${ }^{1}$, Lh. Bazzi², O. Jbara ${ }^{3}$, A. Chihab Eddine ${ }^{4}$, M. Belkhaouda', \\ L. Bammou ${ }^{2}$, R. Salghi ${ }^{5}$, and L. Bazzi ${ }^{1^{*}}$. \\ ${ }^{1}$ Laboratoire Matériaux et Environnement, Faculté des Sciences, Agadir. Morocco. \\ 2 Etablissement Autonome de Contrôle et de Coordination des Exportations, Agadir. Morocco. \\ ${ }^{3}$ Laboratoire d'Ingénierie et Science des Matériaux (LISM), Université de Reims, France. \\ ${ }^{4}$ Laboratoire Chimie Organique, Faculté des Sciences, Agadir. Morocco. \\ ${ }^{5}$ Equipe de Génie de l'Environnement et de Biotechnologie, ENSA, Agadir, Morocco. \\ *E-mail: I.bazzi@uiz.ac.ma
}

\begin{abstract}
Effect of Artemisia plant Extract (APE) on the copper corrosion as a corrosion inhibitor in an aerated acidic solution of in $2 \mathrm{M} \mathrm{H}_{3} \mathrm{PO}_{4}$ containing $3.10^{-1} \mathrm{M} \mathrm{NaCl}$ has been investigated using gravimetric and electrochemical techniques. A significant decrease in the corrosion rate of copper was observed in the presence of the Artemisia plant extract. The potentiodynamic polarization data indicated that the inhibitor was of mixed type. Impedance measurements showed that the charge transfer resistance increased and double layer capacitance decreased with increase in the inhibitor's concentration. Also, some thermodynamic data for the activation are calculated and discussed. The results obtained from potentiodynamic polarization, impedance measurements and gravimetric method are in good agreement.
\end{abstract}

\section{Indexing terms/Keywords}

Artemisia plant extract; corrosion; inhibition; copper; phosphoric acid.

\section{Council for Innovative Research}

Peer Review Research Publishing System

\section{Journal: Journal of Advances in Chemistry}

Vol. 8, No. 3

editor@cirjac.com 


\section{INTRODUCTION}

Copper is metal that has a wide range of applications due to its good properties. It is used in electronics, for production of wires, sheets, tubes, and also to form alloys. Copper is resistant toward the influence of atmosphere and many chemicals, however, it is known that in aggressive media it is susceptible to corrosion. The use of copper corrosion inhibitors in such conditions is necessary since no protective passive layer can be expected. The possibility of the copper corrosion prevention in different aqueous solutions has attracted many researchers so until now numerous possible inhibitors have been investigated. These studies reported that there are a number of organic and inorganic compounds which can do that for the corrosion of copper [1-5]. It is noticed that presence of heteroatoms such as nitrogen, sulphur, phosphorous in the organic compound molecule improves its action as copper corrosion inhibitor. Amongst these organic compounds and their derivatives such as azoles [6,7], amino acids [8] and many others, but these compounds are highly toxic. Recently, the research is oriented to the development of green corrosion inhibitors, compounds with good inhibition efficiency but low risk of environmental pollution [9]. Plant extracts have attracted attention in the field of corrosion inhibition for many decades. As natural products, they are a source of non-toxic, eco-friendly, readily available and renewable inhibitors for preventing metal and alloy corrosion [10-14].

The present study seeks to investigate the potential of using Artemisia plant extract as a cheap and environmentally safe corrosion control agent for copper in $2 \mathrm{M} \mathrm{H}_{3} \mathrm{PO}_{4}$ and $\mathrm{NaCl} 0.3 \mathrm{M}$ solution. The assessment of the corrosion behavior was studied using weight loss, potentiodynamic polarization measurement.

\section{MATERIALS AND METHODS}

\subsection{Weight loss measurements}

Gravimetric methods were conducted on copper test samples of a total surface of $12 \mathrm{~cm}^{2}$. All experiments were carried out under total immersion in $75 \mathrm{ml}$ of test solutions. Mass loss was recorded by an Analytical balance. Prior to each gravimetric or electrochemical experiment, the surface of the specimens was polished successively with emery paper up to 1200 grade, rinsed thoroughly with acetone and bidistilled water before plunging the electrode in the solution. Pure copper samples (99\%) were used. The experiments were carried out in $2 \mathrm{M} \mathrm{H}_{3} \mathrm{PO}_{4}$ medium containing different concentration of $\mathrm{NaCl}$; it was prepared by dilution of Analytical Grade $84 \% \mathrm{H}_{3} \mathrm{PO}_{4}$ with bidistilled water and pure $\mathrm{NaCl}$.

\subsection{Electrochemical tests}

The current-voltage characteristics are recorded with a potentiostat PGZ100 piloted by Voltamaster soft-ware. The scan rate is $30 \mathrm{mV} / \mathrm{min}$ and the potential is ranged from catholic to anodic potentials. Before recording each curve, the working electrode is maintained with its free potential of corrosion $E_{\text {corr }}$ for 30 min. The polarisation curves are obtained from -800 to $500 \mathrm{mV} / \mathrm{SCE}$. We used for all electrochemical tests a cell with three electrodes and double wall thermostats (Tacussel Standard CEC/TH). Saturated calomel (SCE) and platinum electrodes are used as reference and auxiliary electrodes, respectively. The working electrode is in the form of a disc from pure copper of the surface $1 \mathrm{~cm}^{2}$.

The tests were carried out in a temperature range from 298 to $323 \mathrm{~K}$. The electrochemical impedance spectroscopy (EIS) measurements are realised with the electrochemical system (Tacussel), which included a digital potentiostat model Voltalab PGZ100 computer at $E_{\text {corr }}$ after $30 \mathrm{~min}$ immersion in solution. After the determination of steady-state current at a corrosion potential, sine wave voltage $(10 \mathrm{mV})$ peak to peak, at frequencies between $100 \mathrm{kHz}$ and $10 \mathrm{mHz}$ are superimposed on the rest potential. Computer programs automatically controlled the measurements performed at rest potentials after 30 min of exposure at $298 \mathrm{~K}$. The impedance diagrams are given in the Nyquist representation. Experiments are repeated three times to ensure the reproducibility.

\section{RESULTS AND DISCUSSION}

\subsection{Effect of concentration inhibitor}

\subsubsection{Polarization measurements}

Potentiodynamic anodic and cathodic polarization curves of copper specimens in $2 \mathrm{M} \mathrm{H}_{3} \mathrm{PO}_{4}+3.10^{-1} \mathrm{M} \mathrm{NaCl}$ solution in the absence and presence of different concentrations of Artemisia plant extract are shown in Fig. 1. The respective kinetic parameters including corrosion current density $\left(\mathrm{I}_{\text {corr }}\right)$, corrosion potential $\left(\mathrm{E}_{\mathrm{corr}}\right)$, cathodic Tafel slope $\left(\mathrm{b}_{\mathrm{c}}\right)$ and inhibition efficiency $E_{i}(\%)$ are given in Table 1. 


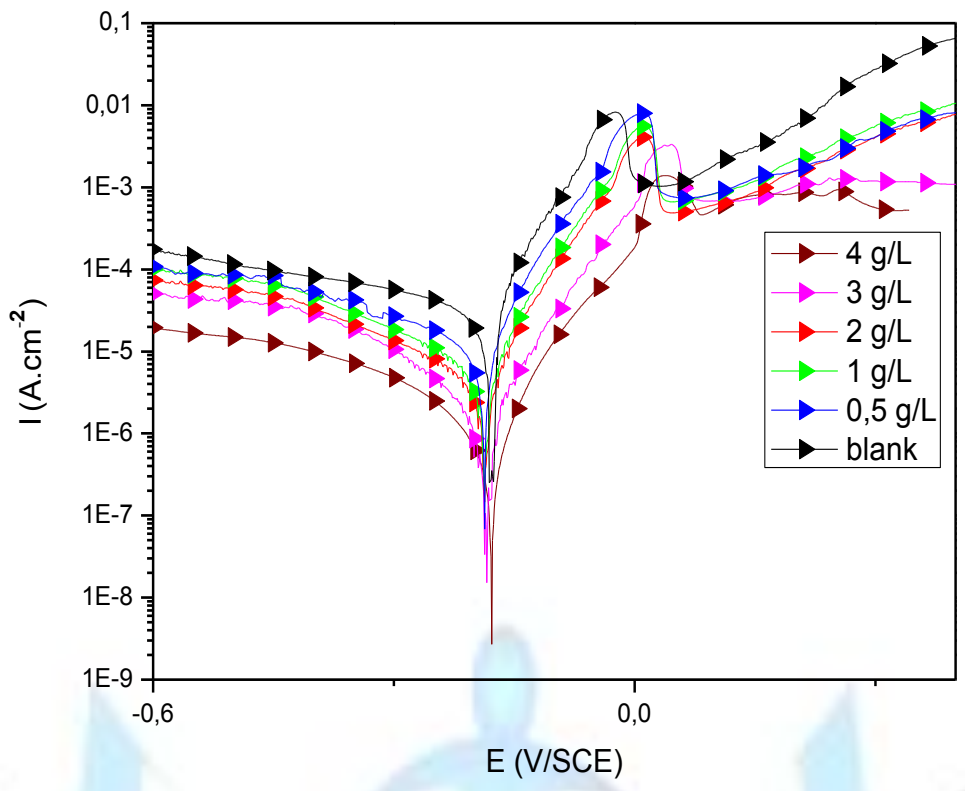

Figure1. Cathodic and Anodic polarisation curves of copper in $\left(2 \mathrm{M} \mathrm{H}_{3} \mathrm{PO}_{4}+3.10^{-1} \mathrm{M} \mathrm{NaCl}\right)$ at different concentrations of APE.

Table 1. Electrochemical parameters of copper at various concentrations of APE in $\left(2 \mathrm{M} \mathrm{H}_{3} \mathrm{PO}_{4}+0.3 \mathrm{M} \mathrm{NaCl}\right)$ and the corresponding inhibition efficiency.

\begin{tabular}{|c|c|c|c|c|c|c|}
\hline Solution & $\begin{array}{c}x \\
(g / L)\end{array}$ & $\begin{array}{c}E_{\text {corr }} \\
\text { (mV/SCE) }\end{array}$ & $\begin{array}{c}I_{\text {corr }} \\
\left(\mu \mathrm{A} / \mathrm{cm}^{2}\right)\end{array}$ & $\begin{array}{c}b_{a} \\
(m V / d e c)\end{array}$ & $\begin{array}{c}b_{c} \\
(m V / d e c)\end{array}$ & $\begin{array}{r}E_{i} \\
(\%)\end{array}$ \\
\hline$\left(2 \mathrm{M} \mathrm{H}_{3} \mathrm{PO}_{4}\right.$ & 0 & -177 & 36 & 68 & -297 & - \\
\hline+ & 0.5 & -187 & 17 & 44 & -365 & 52 \\
\hline $0.3 \mathrm{NaCl})$ & 1 & -187 & 11 & 53 & -337 & 71 \\
\hline+ & 2 & -187 & 8 & 44 & -280 & 80 \\
\hline$x(g / L) A P E$ & 3 & -186 & 3.6 & 44 & -290 & 90 \\
\hline & 4 & -180 & 1 & 50 & -301 & 93 \\
\hline
\end{tabular}

It is illustrated from the data of Table 1 that the addition of Artemisia plant extract decreases corrosion current density. Also, it can be clearly seen that the inhibition efficiency of Artemisia plant extract increases with inhibitor concentration. This behavior shows that Artemisia plant extract acts as a good inhibitor for the corrosion of copper in $2 \mathrm{M}$ $\mathrm{H}_{3} \mathrm{PO}_{4}+3.10^{-1} \mathrm{M} \mathrm{NaCl}$.

The presence of inhibitor results in a marked shift in the cathodic branches and to a lesser extent in the anodic branches of the polarization curves. Moreover, in the presence of Artemisia plant extracts the values of corrosion potential $E_{c o r r}$ are nearly constant; therefore, Artemisia plant extract could be classified as a mixed-type inhibitor with predominant cathodic effectiveness. As can be seen from the data of Table 1, the cathodic Tafel slopes bc are approximately constant, indicating that the inhibiting action occurred by simple blocking of the available surface areas.

\subsubsection{Electrochemical impedance spectroscopy (EIS)}

Electrochemical impedance spectroscopy (EIS) is a well-established and powerful tool in the study of corrosion. Surface properties, electrode kinetics and mechanistic information can be obtained from the impedance diagrams [15].

Various parameters such as charge transfer resistance $\left(R_{t}\right)$, double layer capacitance $C_{d l}$ and percentage inhibition efficiency $\left(E_{R t} \%\right)$ have been calculated and listed in Table 2 . The inhibition efficiency can be evaluated by the following formula: 


$$
E_{R t} \%=\frac{\left(R_{t}-R_{t}^{0}\right)}{R_{t}} \times 100
$$

Here $R_{t}$ and $R_{t}^{0}$ are the charge transfer resistance in inhibited and uninhibited solutions respectively.

The values of the charge transfer resistance were calculated by subtracting the high frequency intersection from the low frequency intersection [16]. Double layer capacitance values $C_{d l}$ were obtained at the frequency ( $\left.f_{\max }\right)$, at which the imaginary component of the Nyquist plot is maximum, and calculated using the following equation.

$$
C_{d l}=\frac{1}{\omega \cdot R_{t}} \quad \text { with } \quad \omega=2 \pi \mathrm{f}_{\max }
$$

It is worth noting that the presence of inhibitor does not alter the profile of impedance diagrams which are almost semi-circular (Fig. 2), indicating that a charge transfer process mainly controls the corrosion of copper.

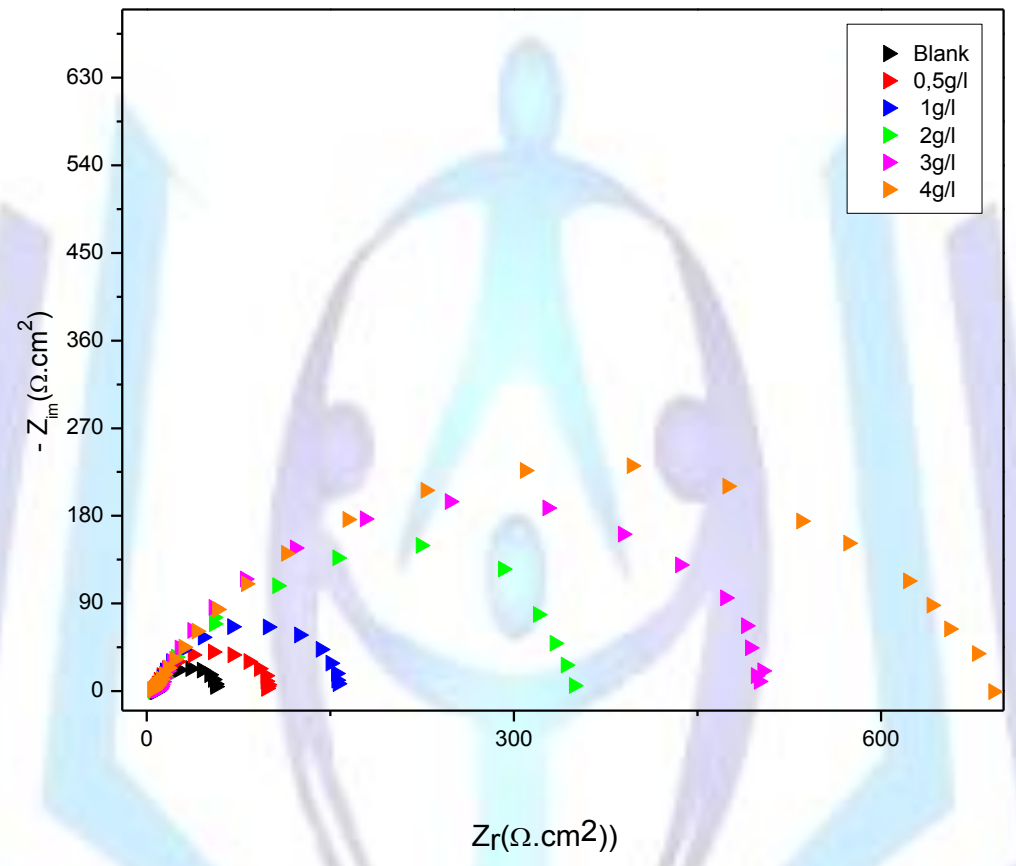

Figure 2. Nyquist diagrams for copper electrode in $\left(2 \mathrm{M} \mathrm{H}_{3} \mathrm{PO}_{4}+0.3 \mathrm{M} \mathrm{NaCl}\right)$ with and without APE after $30 \mathrm{~min}$ of immersion at $\mathrm{E}_{\text {corr. }}$ 
Table 2. Impedance parameters for corrosion of copper in $\left(2 \mathrm{M} \mathrm{H}_{3} \mathrm{PO}_{4}+3.10^{-1} \mathrm{M} \mathrm{NaCl}\right)$ at various concentrations of APE.

\begin{tabular}{|c|c|c|c|c|c|}
\hline & $\begin{array}{c}\text { Concentrations } \\
(\mathrm{g} / \mathrm{L})\end{array}$ & $\begin{array}{c}\mathbf{R}_{\mathrm{t}} \\
\left(\Omega . \mathrm{cm}^{2}\right)\end{array}$ & $\begin{array}{l}f_{\max } \\
(\mathrm{Hz})\end{array}$ & $\begin{array}{c}C_{d l} \\
\left(\mu F / \mathrm{cm}^{2}\right)\end{array}$ & $\begin{array}{l}E_{\mathrm{Rt}} \\
(\%)\end{array}$ \\
\hline Blank & 0 & 50 & 63 & 49 & - \\
\hline$\left(2 \mathrm{M} \mathrm{H}_{3} \mathrm{PO}_{4}\right.$ & 0.5 & 102 & 53 & 29 & 51 \\
\hline+ & 1 & 170 & 40 & 23 & 70 \\
\hline $0.3 \mathrm{NaCl})$ & 2 & 392 & 32 & 12 & 87 \\
\hline+ & 3 & 510 & 30 & 10 & 90 \\
\hline$x(g / L) \quad A P E$ & 4 & 728 & 23 & 9 & 93 \\
\hline
\end{tabular}

From Table 2, it was clear that charge transfer resistance $R_{t}$ values were increased and the capacitance values $C_{d l}$ decreased with increasing inhibitors' concentration. The decrease in the capacitance which can result from a decrease in local dielectric constant and/or an increase in the thickness of the electrical double layer, suggests that the inhibitor molecules act by adsorption at the metal/solution interface.

The presence of APE compounds increases the impedance but does not change other aspects of the behavior. These results support those of polarization measurements that the inhibitor does not alter the electrochemical reactions responsible for corrosion. It inhibits corrosion primarily through its adsorption on the copper surface. The inhibition effect may be due to the various components in plant extract.

\subsubsection{Weight loss, corrosion rates and inhibition efficiency}

Table 3 presents the results of weight loss measurements for the corrosion of copper in $\left(2 \mathrm{M} \mathrm{H}_{3} \mathrm{PO}_{4}+0.3 \mathrm{M} \mathrm{NaCl}\right)$ solutions devoid of and containing different concentrations of the Artemisia extract. Inhibition efficiency $E_{w}$ (\%) is calculated as follows:

$$
\mathrm{E}_{\mathrm{W}}(\%)=\frac{\mathrm{W}_{\text {corr }}-\mathrm{W}^{\prime} \text { corr }}{\mathrm{W}_{\text {corr }}} \times 100
$$

Where $\mathrm{W}_{\text {corr }}$ and $\mathrm{W}^{\prime}$ corr are the corrosion rate of copper in $2 \mathrm{M} \mathrm{H}_{3} \mathrm{PO}_{4}+3.10^{-1} \mathrm{M} \mathrm{NaCl}$ in the absence and presence of APE inhibitor, respectively.

Inspection of the data in the Table 3 reveals that the addition of APE decreases markedly the corrosion rate of copper. This result indicates the inhibitive effect of the added extract on copper corrosion in the acidic solution. The inhibition efficiency increases as the concentration of added extract is increased.

The observed inhibition action of the APE could be attributed to the adsorption of its components on the copper surface. The formed layer, of the adsorbed molecules, isolates the metal surface from the aggressive medium leading to decreasing the corrosion rate. The results obtained from weight loss measurements are in good agreement with that obtained from potentiodynamic polarization and EIS measurements.

Table 3. Copper weight loss data and inhibition efficiency of APE in $2 \mathrm{M} \mathrm{H}_{3} \mathrm{PO}_{4}+0.3 \mathrm{M} \mathrm{NaCl}$.

\begin{tabular}{|c|c|c|c|}
\hline & $\begin{array}{c}x \\
(g / L)\end{array}$ & $\begin{array}{c}W_{\text {corr }}^{\prime} \\
\left(m g \cdot j^{-1} \cdot \mathrm{dm}^{-2}\right)\end{array}$ & $\begin{array}{l}E_{w} \\
(\%)\end{array}$ \\
\hline \multirow{6}{*}{$\begin{array}{c}\left(2 \mathrm{M} \mathrm{H}_{3} \mathrm{PO}_{4}+0.3 \mathrm{NaCl}\right) \\
+x(\mathbf{g} / \mathbf{L}) \quad \text { APE }\end{array}$} & 0 & 162 & - \\
\hline & 0.5 & 81 & 50 \\
\hline & 1 & 52 & 68 \\
\hline & 2 & 32 & 80 \\
\hline & 3 & 14 & 91 \\
\hline & 4 & 8 & 95 \\
\hline
\end{tabular}




\subsection{Effect of the temperature}

\subsubsection{Weight loss tests}

The effect of the temperature on the corrosion rate of the copper in free acid and added with $4 \mathrm{~g} / \mathrm{L} \mathrm{of} \mathrm{APE} \mathrm{at} 8 \mathrm{~h}$ immersion period is made from 298 to $323 \mathrm{~K}$ as shown in Table 4.

Table 4: Effect of the temperature on the copper in $2 \mathrm{M} \mathrm{H}_{3} \mathrm{PO}_{4}+0.3 \mathrm{M} \mathrm{NaCl}$ and added of $4 \mathrm{~g} / \mathrm{L}$ of APE

\begin{tabular}{|c|c|c|c|}
\cline { 2 - 4 } \multicolumn{1}{c|}{} & $\begin{array}{c}\text { Temperature } \\
\mathbf{K}\end{array}$ & $\begin{array}{c}\mathbf{W}^{\prime} \\
\left(\mathbf{m g} \cdot \mathbf{j}^{-1} \cdot \mathbf{d m}^{-2}\right)\end{array}$ & $\begin{array}{c}\mathbf{E}_{\mathbf{w}} \\
\text { (\%) }\end{array}$ \\
\hline \multirow{5}{*}{ Blank } & $\mathbf{2 9 8}$ & 162 & - \\
\cline { 2 - 4 } & $\mathbf{3 0 3}$ & 522 & - \\
\cline { 2 - 4 } & $\mathbf{3 1 3}$ & 777 & - \\
\cline { 2 - 4 } & $\mathbf{3 2 3}$ & 989 & 95 \\
\hline \multirow{5}{*}{ APE } & $\mathbf{2 9 8}$ & 8 & 90 \\
\cline { 2 - 4 } & $\mathbf{3 0 3}$ & 52 & 83 \\
\cline { 2 - 4 } & $\mathbf{3 1 3}$ & 132 & 80 \\
\hline
\end{tabular}

It is clear that the increase of the corrosion rate is more pronounced with the rise of the temperature for blank solution. In the presence of the inhibitor, $W_{\text {corr }}$ is highly reduced.

Also, the inhibition efficiency decreases slightly with increasing temperature. This can be explained by the decrease of the strength of the adsorption processes at elevated temperature and suggested a physical adsorption mode[17]. From this result, we can conclude that APE is an excellent inhibitor.

\subsubsection{Kinetic parameters}

The variation of the logarithm of corrosion rate of the copper in $2 \mathrm{M} \mathrm{H}_{3} \mathrm{PO}_{4}+0.3 \mathrm{M} \mathrm{NaCl}$ at $4 \mathrm{~g} / \mathrm{L} \mathrm{APE}$ as function of temperature reciprocate was illustrated in Fig. 3. It shows that the corrosion reaction can be regarded as an Arrheniustype process equation:

$$
W_{\text {corr }}=\operatorname{kexp}\left(-E_{a} / R T\right)
$$

$$
W_{\text {corr }}^{\prime}=k^{\prime} \exp \left(-E_{a}^{\prime} / R T\right)
$$

Where $\boldsymbol{W}_{\text {cor }}$ and $\boldsymbol{W}_{\text {corr }}^{\prime}$ are the corrosion rates of copper with and without inhibitor, respectively. $\boldsymbol{E}_{\boldsymbol{a}}$ and $\boldsymbol{E}_{\boldsymbol{a}}^{\prime}$ are the apparent activation energies in the presence and absence of inhibitor, respectively. $\boldsymbol{k}$ and $\boldsymbol{k}^{\prime}$ are constants, $\boldsymbol{R}$ is gas constant, $\boldsymbol{T}$ is temperature.

The apparent activation energy was determined from the slopes of $\ln W_{\text {cor }}$ vs $1 / T$ graph depicted in Fig. 3 . It is seen that the presence of APE modifies the values of different activation energies $\left(E_{a}=50 \mathrm{~kJ} / \mathrm{mol} ; E_{a}^{\prime}=83 \mathrm{~kJ} / \mathrm{mol}\right)$. We remark that the activation energy increases in the presence of inhibitor that indicates the poorer performance of APE at higher temperature. The increase of activation energy is generally interpreted by an electrostatic adsorption process of the inhibitor on the copper surface [18,19].

The activation parameters for the studied system $\left(\Delta \mathrm{H}^{*}\right.$ and $\left.\Delta \mathrm{S}^{*}\right)$ were estimated from the transition state equation [20]:

$$
W_{\text {corr }}=\frac{R T}{N h} \cdot \exp \left(\frac{\Delta S^{*}}{R}\right) \cdot \exp \left(-\frac{\Delta H^{*}}{R T}\right)
$$

Where $\mathrm{N}$ is the Avogadro's number, $\mathrm{h}$ the Plank's constant, $\mathrm{R}$ is the perfect gas constant, $\Delta \mathrm{S}^{*}$ and $\Delta \mathrm{H}^{*}$ the entropy and enthalpy of activation, respectively.

Fig. 4 shows a plot of $\ln \left(W_{\text {corr }} / T\right)$ against $1 / T$ for APE. Straight lines are obtained with a slope of $\left(-\Delta H^{*} / R\right)$ and an intercept of (In R/Nh $+\Delta \mathrm{S}^{*} / \mathrm{R}$ ) from which the values of $\Delta \mathrm{H}^{*}$ and $\Delta \mathrm{S}^{*}$ are calculated respectively (Table 5). 


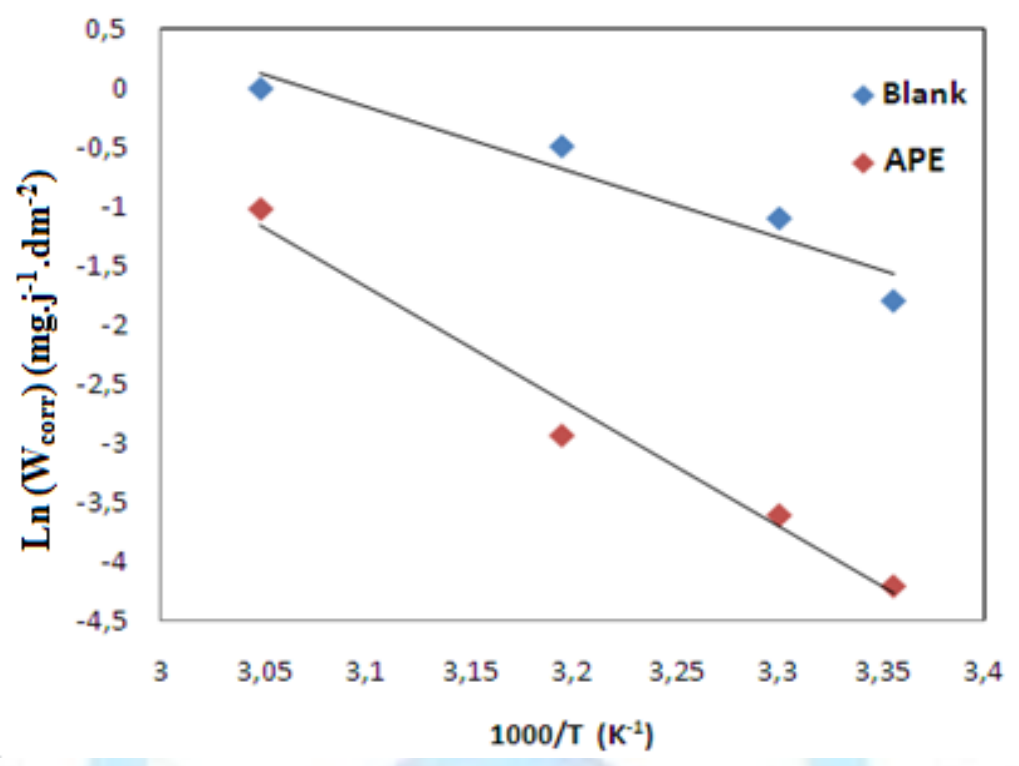

Figure 3. Arrhenius plots of copper in $\left(2 \mathrm{M} \mathrm{H}_{3} \mathrm{PO}_{4}+0.3 \mathrm{M} \mathrm{NaCl}\right)$ with and without $4 \mathrm{~g} / \mathrm{L}$ of APE.

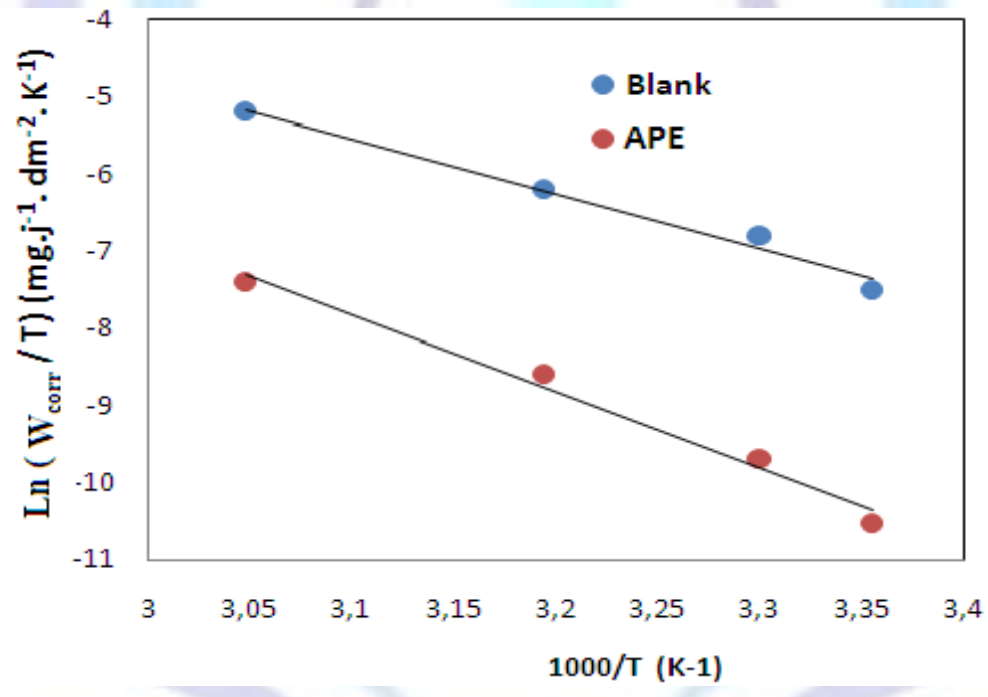

Figure.4 Relation between $\operatorname{Ln}\left(\mathrm{W}_{\text {orr }} / \mathrm{T}\right)$ and 1000/T at different temperatures.

Table 5. The values of activation parameters $\Delta \mathrm{H}^{*}$ and $\Delta \mathrm{S}^{*}$ for copper in $\left(2 \mathrm{M}_{3} \mathrm{PO}_{4}+0.3 \mathrm{M} \mathrm{NaCl}\right)$ in the absence and the presence of $4 \mathrm{~g} / \mathrm{L}$ of APE respectively.

\begin{tabular}{|c|c|c|}
\cline { 2 - 3 } \multicolumn{1}{c|}{} & $\Delta \mathbf{H}^{\star}(\mathbf{k J} / \mathbf{m o l})$ & $\Delta \mathbf{S}^{\star}\left(\mathbf{J} \cdot \mathbf{m o l}^{-1} \cdot \mathbf{k}^{-1}\right)$ \\
\hline Blank & 48 & -111 \\
\hline $\begin{array}{c}\text { Artemisia plant extract } \\
(4 \mathrm{~g} / \mathrm{L})\end{array}$ & 90 & -05 \\
\hline
\end{tabular}

From the data obtained in Table 5, it can be concluded that:

* The positive signs of $\Delta \mathrm{H}^{*}$ reflect the endothermic nature of the copper dissolution process. It is obviously that the activation energy strongly increases in the presence of the inhibitor. Some authors [21- 22] have attributed this result to the inhibitor species being physically adsorbed on the metal surface. 
* The negative values of $\Delta S^{*}$ pointed to a greater order produced during the process of activation. This can be achieved by the formation of an activated complex representing an association or fixation with consequent loss in the degrees of freedom of the system during the process [23].

\section{CONCLUSION}

It can be concluded that:

- As a mixed-type inhibitor APE inhibits the reduction of $\mathrm{H}^{+}$ions by merely blocking the reaction sites of copper surface.

- The inhibition efficiency of APE increases with the concentration to attain a maximum value $93 \%$ at $4 \mathrm{~g} / \mathrm{L}$.

- The effect of temperature on the corrosion behavior of copper indicates that inhibition efficiency of the natural substance decreases slightly with the rise of temperature.

- A good agreement is obtained between the polarization data, electrochemical impedance spectroscopy measurements and gravimetric methods.

\section{References}

1. M. Mihit, S. El Issami, M. Bouklah, L. Bazzi, B. Hammouti, E. Ait Addi, R. Salghi, S. Kertit, Applied Surf. Sci. 252 (2005) 2389.

2. S. El Issami, L. Bazzi, M. Mihit, M. Hilali, R. Salghi, E. Ait Addi, J. Phys. IV France 123 (2005) 307.

3. M. Mihit, R. Salghi, S. El Issami, L. Bazzi, B. Hammouti, E. Ait Addi, S. Kertit, Pigment and Resin Technoloy 35 (2006)151.

4. S. El Issami, M. Mihit, L. Bazzi, R. Salghi, M. Hilali, E. Ait Addi, Transaction of SAEST 40 (2005) 24

5. M. Mihit, M. Belkhaouda, L. Bazzi, R. Salghi, S. El Issami, E. Ait Addi. Port. Electrochim. Acta 25 (2007) 471.

6. E.M.Sherif, S.M. Park, Electrochim. Acta, 51( 2006) 6556.

7. E.M.Sherif, S.Park, Electrochim. Acta, 51 (2006) 4665.

8. J.B. Matos, L.P.Pereira, S.M.L.Agostinho, O.E.Barcia, G.G.O.Cordeiro, E.D.Elia, Electroanal. Chem., 570 (2004) 91.

9. L.R. Chauhan, G. Gunasekaran, Corros. Sci., 49 (2007) 1143.

10. A.M. Abdel-Gaber, B.A. Abd-El-Nabey, I.M. Sidahmed, A.M. El-Zayady, M. Saadawy, Corros. Sci., 48 (2006) 2765.

11. F. Mounir, S. El Issami, Lh. Bazzi, , A. Chihab Eddine, M. Belkhaouda, L. Bammou, R. Salghi, L. Bazzi, O. Jbara., J. Chem. Bio. Phy. Sci. Sec. C, 4(1) (Nov. 2013-Jan. 2014) 516-527.

12. M. Belkhaouda, L. Bammou, A. Zarrouk, R. Salghi, E. E. Ebenso, H. Zarrok, B. Hammouti, L. Bazzi, I. Warad, Int. J. Electrochem. Sci., 8 (2013) $7425-7436$

13. M. Belkhaouda, L. Bammou, R. Salghi, O. Benali, A. Zarrouk, H. Zarrok, B. Hammouti.

J. Mater. Environ. Sci. 5 (6) (2013) 1042-1051

14. L. Bammou, M. Belkhaouda, R. Salghi, O. Benali, A. Zarrouk, S. S. Al-Deyab, I. Warad, H. Zarrok, B. Hammouti, Int. J. Electrochem. Sci., 9 (2014) 1506 - 1521.

15. W.J. Lorenz, F. Mansfeld, Determination of corrosion rates by electrochemical DC and AC methods, Corr. Sci. 21 (1981) 647-672.

16. O. Ouachikh, A. Bouyanzer, M. Bouklah, J-M. Desjobert, J. Costa, B. Hammouti, L. Majidi, Surface Review and Letters, 16 (2009) 49.

17. M. Bouklah, A. Attayibat, S. Kertit, A. Ramdani and B. Hammouti, App/ Surf Sci 242 (2005) 399

18. A. Popova, E. Sokolova, S. Raicheva and M. Christov, Corros Sci 45 (2003) 33

19. T. Szauer and A. Branbt, Electrochim Acta 22 (1981) 1209

20. S.S. Abd-El-Rehim, S.A.M. Refaey, F. Taha, M.B. Saleh and R.A. Ahmed, J Appl Electrochem 31(2001) 429.

21. A. Bouyanzer and B. Hammouti, Pigm Resin Technol 33 (2004) 287

22. Y. Abboud, A. Abourriche, T. Ainane, M. Charrouf, A. Bennamara and O. Tanane, Chem Eng Commun, 196 (2009) 788

23. S.S. Abd-El-Rehim, S.A.M. Refaey, F.Taha, M.B.Saleh, R.A.Ahmed, J.Appl. Electrochem. 31(2001)429. 